International Journal of Linguistics, Literature and Translation

ISSN: 2617-0299 (Online); ISSN: 2708-0099 (Print)

DOI: 10.32996/ijllt

Journal Homepage: www.al-kindipublisher.com/index.php/ijltt

IJLLT

\title{
Relationship between Iranian EFL Learners' Learning Styles and Their Performance on Reading Journalistic Texts: A Gender Perspective
}

\author{
Mehrnoush Haddad ${ }^{1}$ (ID) and Mohsen Shahrokhi ${ }^{2}$ (ID) $ه$ \\ ${ }^{1}$ Department of English, Faculty of Humanities, Najafabad Branch, Islamic Azad University, Najafabad, Iran \\ 2Department of English, Shahreza Branch, Islamic Azad University, Shahreza, Iran
}

$\triangle$ Corresponding Author: Mohsen Shahrokhi, E-mail: shahrokhi1651@yahoo.com

ARTICLE INFORMATION
Received: March 08, 2021
Accepted: April 28, 2021
Volume: 4
Issue: 4
DOI: $10.32996 /$ ijllt.2021.4.4.31

\section{KEYWORDS}

Learning styles, journalistic text, gender, reading performance

\section{ABSTRACT}

This paper examined the relationship between upper intermediate female and male EFL learners' learning styles and their performances on reading journalistic texts. Moreover, the study checked whether the gender of the participants has any impact on their performances on reading journalistic text styles. To this end, 30 female and 30 male homogeneous participants aged 22 to 45 years old, were selected based on their performance on Oxford Placement Test (OPT). To identify the participants' learning styles, a questionnaire was distributed among the participants. The participants also sat for a test of reading journalistic texts designed by the researchers. The results indicated that learning style as a composite variable could predict the female learners' reading of journalistic materials, and that group learning style was significantly correlated with reading journalistic texts. The data analysis, furthermore, revealed that learning style could not significantly predict male EFL learner's performance on journalistic reading texts. Moreover, the differences between the learning styles of male and females EFL learners could not bring about significant changes in their reading journalistic texts. The results have some implications for EFL teachers and students, material developers, and curriculum designers.

\section{Introduction}

Learning style (LS) has been defined by various scholars mostly as a signal for individual differences (Rezaee \& Abidin, 2011). These differences may manifest themselves in 'life styles' and even in personality types (Zhang \& Sternberg, 2005). Learning style has cognitive, affective, and psychological aspects. Cognitive components deal with the internal control of the system of running the knowledge and these can be changed through education. Affective and psychological components affect the preferences of the individual and suggest answers to both education and teaching strategies (Kazo, 2009). LS is the way in which each person begins to concentrate on, process and retain new and difficult information through different perceptual channels. Styles pertain to the person as an individual, and that differentiate her/him from someone else. It is generally assumed that LS refer to beliefs, preferences, and behaviors used by individuals to aid their learning in a given situation (Brown, 2000).

Reid (cited in Davis \& Elder, 2004, p. 535) distinguished four perceptual learning modalities, namely "visual, auditory, kinesthetic, and, tactile" and two social styles, namely "group and individual styles". Auditory learners are "students who enjoy the oral-aural learning channel. Thus they want to engage in discussions, conversations, and group work. These students typically require only oral directions" (Oxford, 1995, p.36 as cited in Sheikhi, 2009). Visual learners are learners who "prefer to learn via the visual channel. Therefore, they like to read a lot, which requires concentration and time spent alone. Visual students need the visual stimulation of bulletin boards, videos and movies. They must have written directions if they are to function well in the classroom" (Oxford, 1995, p. 35 as cited in Sheikhi, 2009). The kinesthetic learning style "implies total physical involvement with a learning environment such as taking a field trip, dramatizing, pantomiming, or interviewing" (Kinsella, 1995). Tactile learning "suggests learning with one's hands through manipulation or resources, such as writing, drawing, building a model, or conducting a lab

$\begin{array}{lllll}\mathbf{K} & \mathbf{C} & \text { AL-KINDI CENTER } \\ \mathbf{R} & \mathbf{D} & \text { FOR RESEARCH AN }\end{array}$ R D DEVELOPMENT Your gateway to world-class research

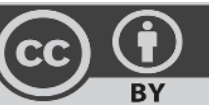

Published by Al-Kindi Center for Research and Development, London, United Kingdom. Copyright (c) the author(s). This open access article is distributed under a Creative Commons Attribution (CC-BY) 4.0 license 
experiment (Kinsella, 1995, p. 172 as Cited in Sheikhi, 2009). A group learner is the one who "learns more effectively through working with others" (Reid, 1995). An individual learner is someone who "learns more effectively through working alone" (Reid, 1995, Sheikhi, 2009). Willing (1987, cited Davis \& Elder, 2004, p. 535) distinguished two intersecting dimensions of style: holistic versus analytic (similar to the field dependence/independence distinction) and active versus passive styles.

Skehan (cited in Davis \& Elder, 2004, p. 38) shows that the various styles identified by different researchers can be slotted into a framework based on "three stages of acquisition (input, central processing and output/retrieval) and on whether the focus is information processing or knowledge representation". This indicates how different models of learning style give emphasis to different aspects of language acquisition.

According to Sheng (2000), reading is a process of communication from the writer to the reader involving the recognition of letters, words, phrases, and clauses, and a process of negotiation between the reader and the writer. The knowledge of the language, experience of a particular genre of reading influences the meaning a reader derives from a text (Rico, 2013). A genre is a form of text that uses a particular format and structure (Duke \& Purcell- Gates, 2003). A genre comprises a class of communicative events, the members of which share some set of communicative purposes. These purposes are recognized by the expert members of the parent discourse community and thereby constitute the rationale for the genre (Swales, 1990). Genre analysis is a developing multi-disciplinary approach to the study of texts, both verbal and written, drawing from studies in linguistics, anthropology, sociology and psychology. Genre analysts look for the common patterns of grammar usage, key vocabulary, and text structure in particular text types (Bradford-Watts, 2003). Genre analysis as a sub-discipline in applied linguistic emerged in the 1980s and blossomed in the 1990s. A genre is a highly structured and conventionalized discourse which occurs among the members of a community (Bonyadi, 2012). For instance, as far as journalistic texts are concerned, several genres, for example, scientific, cultural, sport, political, social genres, are used in journals (Duke, 1979).

According to Paltridge (2002), genre knowledge includes an understanding of the social and cultural contexts of genres, the language choices within the genres, and a sense of what is and what is not appropriate in certain contexts which reflect the norms and values of a discourse community is important for second language learners. According to Marques (as cited in Saraiva, 2006), language in a journalistic text should be objective, unbiased, unambiguous, clear and as simple as possible. Suppressing the use of first-person singular or plural is one of the ways to achieve that avoiding imprecise references, such as some and most, objectives and hyperbole are also some cares that should be observed in writing a journalistic text.

Rogers and Thorson, (2003, p. 659, cited in Whal-Jorgensen \& Hanitzch, 2009) contend that "men and women socialize differently into the workplace because men and women have different values and priorities". Rogers and Thorson's content analysis of three newspapers found that women drew upon a greater variety of female and ethnic sources, especially in positive stories, but women at the large paper sourced and framed stories much like their male counterpart.

\section{Statement of Problem}

The reading comprehension process is the readers' ability to obtain information for some purpose and to find out some information to check or clarify (Doff, 1998). Reading is one of the most important skills that all foreign language learners should know for different purposes, including getting information and improving the knowledge of the language. Besides, the comprehension of what is read is the basic goal for those who want to gain an understanding of the world and of themselves (Tierney, 2005).

Journalistic texts are not merely descriptions of reality; they should be understood as strategic interpretations of reality, offering the interpreter the possibility of asserting moral authority (Broersma, 2007). Some journalistic reading texts present an inconsistency between title and text. The title mentions something not discussed in the text (2006, Schröder \& Perna). Insufficient knowledge of vocabulary and sentence structure causes problems of reading journalistic comprehension texts (Chawwang, 2008). Complex noun groups, nominalizations, coordinating conjunctions, participial phrases, and prepositional phrases are the main causes of problems in reading journalistic comprehension texts among the students because they render texts complex and difficult to understand (Nuttall, 2000). An unfamiliar cultural context and distinguishing between content knowledge of culture and knowledge of vocabulary cause problems in reading because the reader does not clearly understand the other culture. In addition, inadequate knowledge of text type is a problem in reading texts. The text type such as newspaper articles, fairy tales, and business letters, if the reader does not know what kind of the text, he cannot follow and understand what the text is about. A reader can understand a text if he is familiar with the text type (Alderson, 2002). Limited knowledge of vocabulary and sentence structure is regarded as the main problem for students reading texts (Gunning, 2002).

Reading teachers could create reading strategies that address specific sensory learning styles to help support these learners as they develop their reading abilities (William, 2010). Students' performance may be related to learning preferences or styles as learners. Students may also self-select into or away from classes based on their learning preferences. As a result, students' 
success in classes may ultimately depend on understanding the learning style characteristics of the students who enrol in course (Kadir, 2013).

Reid (1987), in his research, stated that students with their variety of language and cultural backgrounds and differences in age and previous education often come together in programmes in which they are taught homogeneously by teachers who have little knowledge of learning styles. The concern of the current study is to better understand the different learning styles among EFL students for improving reading journalistic texts.

\section{Research Objectives and Questions}

The present study tries to examine the relationship between Iranian upper intermediate EFL learners' learning styles and their performance on reading journalistic texts. The objective behinds journalistic text reading is to make students familiar with journalistic terms and terminology and English journalistic genres. Moreover, the study aims at checking the possible relationship between learning style and reading journal text performance. Finally, the study is going to shed more light on the possible differences between male and female EFL learners learning style as another objective. Accordingly, the following research questions were posed in the current study.

$\mathbf{R Q}_{1}$. Is there any significant relationship between Iranian upper intermediate female EFL learners' learning styles and their performance on reading journalistic texts?

$\mathbf{R Q}_{2}$. Is there any significant relationship between Iranian upper intermediate male EFL learners' learning styles and their performance on reading journalistic texts?

$\mathbf{R Q}_{3}$. Is there any significant difference between female and male EFL learners' performance on reading journalistic texts in relation to their learning styles?

\section{Method}

\subsection{Research Design}

The design of study is a quantitative one and it adopts a descriptive-correlational method. The main independent variable of the study is learning styles, whose impact is going to be checked on reading journalistic text performance as the dependent variable of the study in relation with gender as the second independent variable of the study.

\subsection{Participants}

The population to which the researcher would like to generalize the results of the study is Iranian EFL learners. Accordingly, convenience sampling was used for selecting the participants of this study. The participants of this study were 60 (30 males and 30 females) upper-intermediate EFL learners of English studying at Ahvaz Branch, Islamic Azad University, Ahvaz, Iran. Their age ranged between 22 to 45 years old. Participants were selected based on their performance on an Oxford Placement Test (OPT). The participants were all assured that their results and identities would be kept confidential.

\subsection{Instruments}

In order to collect the required data of the study, a few instruments which had been designed to measure the variables of the study were used. The instruments included a placement test, i.e. Oxford Placement test, a questionnaire to measure the learning style of the participants, and a post test to measure the participants' reading comprehension test.

\subsubsection{Oxford Placement Test (OPT)}

The test was divided into three parts: vocabulary and reading, grammar, writing sections. Part one includes 50 items in multiplechoice format and cloze-test reading format; and part two includes 10 items and part three includes writing task. All the test items were in multiple-choice formats. This test was used to examine concurrent validity and homogeneous participants. Depending on the timing during the piloting, it was decided that 60 minutes was ideal for students to respond to the questions.

\subsubsection{Learning Style Questionnaire}

The questionnaire used in the study included six learning styles (visual, auditory, kinesthetic, tactile, group, individual) and was originally developed by Reid (1995). The questionnaire included three major sections. Section A elicited demographic information. Section B consisted of 30items that measured different learning styles. Items $6,10,12,24$, and 29 checked the visual styles of the participants. Items 11, 14, 16, 22, and 25 checked the tactile style; items 1, 7, 9, 17, and 20 dealt with auditory style; group style was checked through items $3,4,5,21$, and 23; kinesthetic style was checked by items 2, 8, 15, 19, and 26; and items $13,18,27,28,30$ dealt with individual style. Section $C$ of the questionnaire described the scoring procedure of the data.

The questionnaire benefited from an international reputation that confirmed its validity and its reliability. However, its reliability was checked in a pilot study by the researcher through Cronbach's alpha and turned out to be .73. The questionnaire was also confirmed by two university professor of Applied Linguistics in terms of validity. 


\subsubsection{Reading Journalistic Test}

The test was designed by the researcher of the study to measure the participants' reading journalistic text comprehension. The test included four texts based on which 30 items were developed. The journalistic texts included such materials as social, political, health, and science and were downloaded from online archives of journals. The journalistic texts were chosen from online magazines, namely Success and Woman Health, and online newspapers namely, New York Times and Washington Post. Reading journalistic texts were published from January 2016 to March 2020. The reason behind the selection of these newspapers was the ease of accessibility and circulation, and because most of the English newspapers were not free.

The items included a variety of forms, including multiple choices, open ended questions, and cloze test questions. Two university teachers checked the test in order to confirm the validity. The test was checked in terms of its reliability and the reliability of the test was determined .81 through KR-21 method.

\subsection{Procedures}

First, the students were asked to sit for Oxford Placement Test (OPT), including a set of multiple-choice questions to measure their general English proficiency and select a homogenized sample. Once the sampling of the study was performed the selected students were asked to fill in the English version of the learning style preference questionnaire. The students could respond to the questions without any time limitation. To increase the credibility of the responses, the researcher reminded the students that they should be sincere in their answers and they should not spend too much time on any of the times. The students were also asked to give an immediate response, avoid hesitation in responding, and changing their answers. The researcher was present during the steps of data collection to make sure the participants have no problem understanding the questionnaire items. The questionnaires were collected and the responses were entered into the computer for data analyses. In the next step, the reading journalistic test designed by the researcher was completed. The students were required to complete the test in 60 minutes. The time that was allotted for the completion of the test was also determined according to the pilot study results. The responses students were entered into the computer for data analysis. The questionnaire and the reading test were completed during class time.

\subsection{Data Analyses}

The data underwent statistical analysis. The Statistical Package for Social Sciences (SPSS) version 22 was used. To determine significant relationship between upper intermediate EFL learners' learning styles and their performance on reading journalistic texts, multiple regression correlation procedure was used; and to identify the likely significant differences between female and male EFL learners' reading performance on reading journalistic texts a series of $t$-tests were run.

\section{Results}

The present study used an ex post facto design to investigate the relationship between male and female EFL Learners' learning styles and their performances on reading journalistic texts from one hand and to examine the possible differences between male and female learners with respect to different learning styles, on the other hand.

\subsection{First Research Question}

The first research question of the study asked "Is there any significant relationship between Iranian upper intermediate female EFL learners' learning styles and their performance on reading journalistic texts?" Since learning style could be considered to be a composite variable (consisting of visual, auditory, tactile, kinesthetic, individual, and group subcomponents), the causal relationship between this composite variable and reading journalistic texts was investigated through multiple regression analysis. Table 1 shows the correlation coefficients for the relationship between female EFL learners' journalistic text scores (JTS) and their learning style components.

Table 1. Correlation Coefficients for the Relationship between Learning Style Components and JTS of Female EFL Learners

\begin{tabular}{llrrrrrrr}
\hline & & JTS & Visual & Auditory & Kinesthetic & Tactile & Group & Individual \\
\hline Pearson Correlation & JTS & 1.00 & .19 & -.17 & .13 & .21 & $.53^{*}$ & .24 \\
& Visual & .19 & 1.00 & $.47^{*}$ & .27 & .24 & $.33^{*}$ & .24 \\
& Auditory & -.17 & $.47^{*}$ & 1.00 & .07 & .11 & -.17 & $.39^{*}$ \\
& Kinesthetic & .13 & .27 & .07 & 1.00 & $.60^{*}$ & $.30^{*}$ & .18 \\
& Tactile & .21 & .24 & .11 & $.60^{*}$ & 1.00 & $.31^{*}$ & .17 \\
& Group & $.53^{*}$ & $.33^{*}$ & -.17 & $.30^{*}$ & $.31^{*}$ & 1.00 & .01 \\
& Individual & .24 & .24 & $.39^{*}$ & -.18 & $-.17^{*}$ & .01 & 1.00 \\
\hline
\end{tabular}

Note: * means a significant relationship

The relationship between JTS and visual style was a weak positive one $(r=.19)$, and this relationship was not of statistical significance. Likewise, JTS was weakly and insignificantly correlated with auditory style $(r=-.17)$, kinesthetic style $(r=.13)$, tactile 
style $(r=.21)$, and individual learning style $(r=.24)$. However, the relationship between JTS and group learning style was a moderate significant one $\left(r=.53^{*}\right)$. To find out whether the different components of learning style could account for success or failure in reading journalistic texts, one needs to examine the multiple regression analyses tables below.

Table 2. Model Summary for Multiple Regression for Female Learners

\begin{tabular}{ccccc}
\hline Model & $\boldsymbol{R}$ & $\boldsymbol{R}$ Square & Adjusted R Square & Std. Error of the Estimate \\
\hline 1 & .63 & .40 & .25 & 5.63 \\
\hline
\end{tabular}

In Table 2, the value given under the $R$ Square column shows how much of the variance in JRS is explained by learning style. The value here is .40. This means that learning style accounted for 40 per cent of the variance in journalistic text scores. To examine the statistical significance of this result, Table 3 should be consulted.

Table 3. Statistical Significance of the Multiple Regression Results for Female Learners

\begin{tabular}{lccccc}
\hline & Sum of Squares & $\boldsymbol{d} \boldsymbol{f}$ & Mean Square & $\boldsymbol{F}$ & Sig. \\
\hline Regression & 500.23 & 6 & 83.37 & 2.62 & .04 \\
Residual & 729.93 & 23 & 31.73 & & \\
Total & 1230.16 & 29 & & & \\
\hline
\end{tabular}

In Table 3, the Sig. Value equaled .04, which is smaller than the alpha level $(p=.04<.05)$, indicating that the model reached a statistical significance. In other words, learning style (as a composite variable) could significantly predict JTS of female EFL learners. Table 4 reveals which of the components of learning style contributed more to the prediction of JTS.

Table 4. Predictive Power of Learning Style Components for JRS of Female Learners

\begin{tabular}{|c|c|c|c|c|c|c|c|c|c|c|c|c|}
\hline & \multicolumn{3}{|c|}{$\begin{array}{ll}\text { Unstandardized } & \text { Standardized } \\
\text { Coefficients } & \text { Coefficients }\end{array}$} & \multirow[b]{2}{*}{$t$} & \multirow[b]{2}{*}{ Sig. } & \multicolumn{2}{|c|}{$\begin{array}{c}\text { Confidence } \\
\text { Interval for B }\end{array}$} & \multicolumn{3}{|c|}{ Correlations } & \multicolumn{2}{|c|}{$\begin{array}{l}\text { Collinearity } \\
\text { Statistics }\end{array}$} \\
\hline & $B$ & $\begin{array}{l}\text { Std. } \\
\text { Error }\end{array}$ & Beta & & & $\begin{array}{l}\text { Lower } \\
\text { Bound }\end{array}$ & $\begin{array}{l}\text { Upper } \\
\text { Bound }\end{array}$ & $\begin{array}{l}\text { Zero- } \\
\text { order }\end{array}$ & Partial & Part & Tolerance & VIF \\
\hline Visual & .42 & 1.07 & .08 & .39 & .69 & -1.80 & 2.65 & .19 & .08 & .06 & .58 & 1.71 \\
\hline Auditory & -1.75 & 1.22 & -.30 & - & .16 & -4.28 & .77 & -.17 & -.28 & -.23 & .56 & 1.78 \\
\hline Kinesthetic & -.11 & .94 & -.02 & 1.43 & .90 & -2.07 & 1.84 & .13 & -.02 & -.01 & .59 & 1.68 \\
\hline Individual & 2.81 & 1.41 & .37 & $\begin{array}{l}1.99 \\
1.99\end{array}$ & .06 & -.10 & 5.73 & .24 & .38 & .32 & .74 & 1.34 \\
\hline
\end{tabular}

To compare the predictive power of the visual, auditory, kinesthetic, tactile, group, and individual learning styles, the values under Beta in the column standardized coefficients should be checked. Looking down this column, one could notice that the largest value was the one for the group (.39). Group learning style thus made the strongest unique contribution to explaining journalistic text reading score. The relevant Beta value for individual learning style (.37) was the second-highest value out there, indicating that it made less of a contribution. The other values were $-.30, .19, .08$, and -.02 respectively for auditory, tactile, visual, and kinesthetic learning styles; these learning styles' contributions to the prediction of JTS were very small. None of the components of learning style had a Sig. Value less than the significance level (.05); it could thus be concluded that among the visual, auditory, kinesthetic, tactile, group, and individual learning styles, none could significantly predict JTS of female EFL learners.

\subsection{Second Research Question}

As it was previously pointed out, the second research question of the study asked "Is there any significant relationship between Iranian upper-intermediate male EFL learners' learning styles and their performance on reading journalistic texts?" Like what was done for the first research question, multiple regression analysis was used again to see whether different components of learning style could account for male learners' journalistic text reading scores or not. Table 5 shows the Pearson correlation coefficients for the relationship between JTS of male learners and their learning style components.

Table 5. Correlation Coefficients for the Relationship between Learning Style Components and JTS of Male EFL Learners JRS Visual Auditory Kinesthetic Tactile Group Individual

\begin{tabular}{llrrrrrrr}
\hline Pearson Correlation & JRS & 1.00 & .10 & -.28 & -.28 & -.21 & .18 & -.04 \\
& Visual & .10 & 1.00 & -19 & .13 & $.34^{*}$ & .09 & .21 \\
& Auditory & -.28 & -.19 & 1.00 & .07 & .06 & .17 & $.36^{*}$ \\
\hline
\end{tabular}




$\begin{array}{lrrrrrrr}\text { Kinesthetic } & -.28 & .13 & .07 & 1.00 & .46^{*} & -.06 & -.10 \\ \text { Tactile } & .21 & .34 & .06 & .46^{*} & 1.00 & -.16 & -.002 \\ \text { Group } & .18 & .09 & .17 & -.06 & -.16 & 1.00 & .19 \\ \text { Individual } & -.04 & .21 & .36^{*} & -.10 & -.002 & .19 & 1.00\end{array}$

Note: * means a significant relationship

According to Table 5, the relationship between JTS and visual style was a weak positive relationship $(r=.10)$, which was not statistically significant. The relationship between JTR on the one hand and all other learning styles, on the other hand, were also weak: for the relationship between JTR and auditory style and the kinesthetic style of the male learners $(r=-.28)$, there was a weak negative relationship; so was the relationship between JTR and tactile learning style of males EFL learners $(r=-.21)$; JTS was positively correlated with group learning style $(r=.18)$, but negatively with individual $(r=-.04)$ learning style. None of these correlations were statistically significant. In order to see whether learning style can significantly account for JTS of male EFL learners, the multiple regression results in Table 6 were provided.

Table 6. Model Summary for Multiple Regression for Male Learners

\begin{tabular}{ccccc}
\hline Model & $\boldsymbol{R}$ & $\boldsymbol{R}$ Square & Adjusted R Square & Std. Error of the Estimate \\
\hline 1 & .45 & .20 & .000 & 7.54 \\
\hline
\end{tabular}

The value given under the $R$ Square column was .20. This means that variance in learning style could account for 20 percent of the variance in journalistic reading scores of male Iranian EFL learners. Table 7 examines the statistical significance of this result.

Table 7. Statistical Significance of the Multiple Regression Results for Male Learners

\begin{tabular}{lccccc}
\hline & Sum of Squares & $\boldsymbol{d f}$ & Mean Square & $\boldsymbol{F}$ & Sig. \\
\hline Regression & 341.79 & 6 & 56.99 & .99 & .44 \\
Residual & 1311.00 & 23 & 57.00 & & \\
Total & 1652.80 & 29 & & & \\
\end{tabular}

The Sig. value in Table 7 was .44 , which is greater than the level of significance $(p=.44>0.05)$. This would mean that learning style (as a composite variable) could not significantly predict male learners' JTS. A quick look at Table 4.8 shows whether any of the components of learning style significantly contributed to the prediction of JTS of male EFL learners or not.

Table 8. Predictive Power of Learning Style Components for JTR of Male Learners

\begin{tabular}{|c|c|c|c|c|c|c|c|c|c|c|c|c|}
\hline & \multicolumn{2}{|c|}{$\begin{array}{l}\text { Unstandardized } \\
\text { Coefficients }\end{array}$} & \multirow{2}{*}{$\begin{array}{c}\begin{array}{c}\text { Standardized } \\
\text { Coefficients }\end{array} \\
\text { Beta }\end{array}$} & \multirow[b]{2}{*}{$t$} & \multirow[b]{2}{*}{ Sig. } & \multicolumn{2}{|c|}{$\begin{array}{c}\text { Confidence } \\
\text { Interval for B }\end{array}$} & \multicolumn{3}{|c|}{ Correlations } & \multicolumn{2}{|c|}{$\begin{array}{l}\text { Collinearity } \\
\text { Statistics }\end{array}$} \\
\hline & $B$ & Std. Error & & & & $\begin{array}{l}\text { Lower } \\
\text { Bound }\end{array}$ & $\begin{array}{l}\text { Upper } \\
\text { Bound }\end{array}$ & $\begin{array}{l}\text { Zero- } \\
\text { order }\end{array}$ & Partial & Part & Tolerance & VIF \\
\hline Visual & 1.30 & 2.66 & .10 & .48 & .62 & -4.21 & 6.82 & .10 & .10 & .09 & .71 & 1.39 \\
\hline Auditory & -1.36 & 1.13 & -.26 & -1.2 & .24 & -3.71 & .98 & -.28 & -.24 & -.22 & .72 & 1.37 \\
\hline Kinesthetic & -.44 & 1.08 & -.09 & -.40 & .68 & -2.69 & 1.80 & -.21 & -.08 & -.07 & .65 & 1.52 \\
\hline Individual & 2.15 & 2.20 & .19 & .97 & .33 & -2.40 & 6.72 & -.18 & 2.00 & .18 & .88 & 1.12 \\
\hline Group & -.28 & 1.80 & -.03 & -.15 & .87 & -4.01 & 3.44 & -.04 & -.03 & -.03 & .74 & 1.33 \\
\hline
\end{tabular}

Looking down the Standardized Coefficients column, one could see that the largest value, irrespective of any negative marks, was the one for auditory (Beta $=-.26$ ). Auditory learning style, thus, made the strongest unique contribution to explaining JTS of male EFL learners, which was totally different from what was obtained for female learners. The relevant Beta value for tactile learning style was the second-highest value out there (Beta = -.22), indicating that it made less of a contribution. Then there were individual learning style (Beta $=.19)$, visual $(.10)$, kinesthetic $(-.09)$, and group (-.03) learning styles. The Sig. values for all different types of learning style were larger than the significance level, indicating that none of the learning styles could significantly predict JTS of EFL learners. 


\subsection{Third Research Question}

The third research question in hand asked "Is there any significant difference between female and male EFL learners' performance on reading journalistic texts in relation to their learning styles?" To compare male and female learners' visual learning style, an independent samples $t$ test was employed. The same statistical tool was used for making comparisons between male and female learners' auditory, tactile, kinesthetic, individual, and group learning styles, and also for comparing their journalistic reading scores. Table 9 shows the descriptive statistics related to these analyses.

Table 9. Descriptive Statistics for Comparing Male and Female Learners' Learning Styles and JRS

\begin{tabular}{llllcc}
\hline & Gender & $\boldsymbol{N}$ & Mean & $\begin{array}{c}\text { Std. } \\
\text { Deviation }\end{array}$ & Std. Error Mean \\
\hline \multirow{2}{*}{ Visual } & Female & 30 & 3.90 & 1.26 & .23 \\
\hline \multirow{2}{*}{ Auditory } & Male & 30 & 4.60 & .62 & .11 \\
\hline \multirow{2}{*}{ Kinesthetic } & Female & 30 & 3.93 & 1.14 & .20 \\
\cline { 2 - 6 } & Male & 30 & 3.66 & 1.44 & .26 \\
\hline \multirow{2}{*}{ Tactile } & Female & 30 & 3.86 & 1.43 & .26 \\
\hline \multirow{2}{*}{ Group } & Male & 30 & 4.16 & .83 & .15 \\
\hline \multirow{2}{*}{ Individual } & Female & 30 & 2.80 & 1.73 & .31 \\
\cline { 2 - 6 } & Male & 30 & 3.23 & 1.59 & .29 \\
\hline \multirow{2}{*}{ Journalistic Text Score } & Female & 30 & 3.56 & 1.35 & .24 \\
\cline { 2 - 6 } & Male & 30 & 4.60 & .67 & .12 \\
\hline & Female & 30 & 4.56 & .85 & .15 \\
\cline { 2 - 6 } & Male & 30 & 3.86 & .89 & .16 \\
\hline
\end{tabular}

Such descriptive statistics as mean scores and standard deviations of male and female EFL learners for visual, auditory, tactile, kinesthetic, individual, and group learning styles and for their journalistic reading scores are shown in Table 9. There were differences in the mean scores of males and females for these six learning styles and for their journalistic reading scores. The relevant values of $p$ under the Sig. (2-tailed) column in Table 10 determines whether these differences between the mean scores of males and females were statistically significant or not.

Table 10. Results of the Independent-Samples t-test for Comparing Male and Female Learners' Learning Styles' and JRS

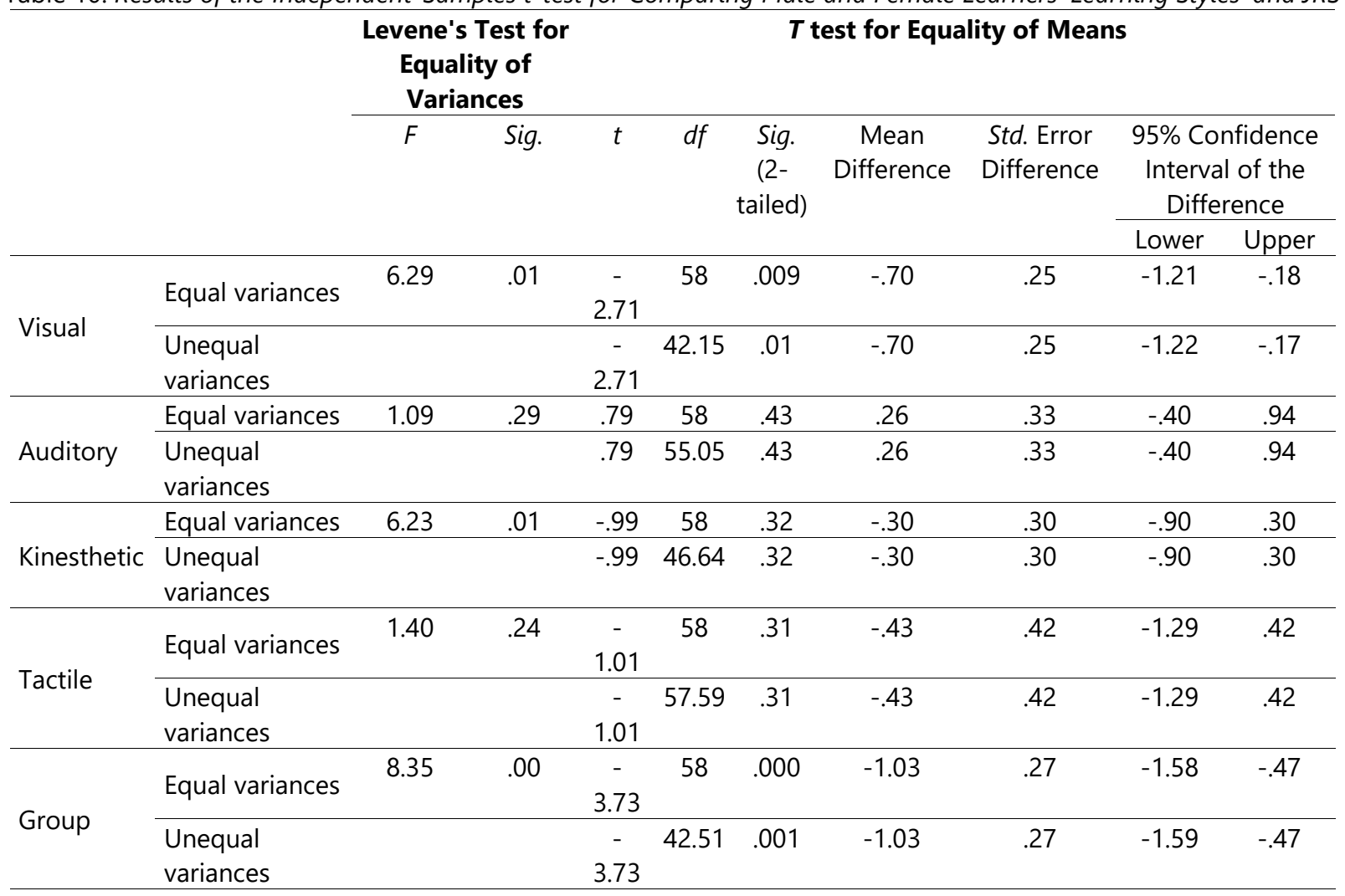




\begin{tabular}{|c|c|c|c|c|c|c|c|c|c|c|}
\hline & Equal variances & 1.24 & .27 & 3.08 & 58 & .003 & .70 & .22 & .24 & 1.15 \\
\hline Individual & $\begin{array}{l}\text { Unequal } \\
\text { variances }\end{array}$ & & & 3.08 & 57.87 & .003 & .70 & .22 & .24 & 1.15 \\
\hline & Equal variances & .40 & .52 & .56 & 58 & .57 & 1.03 & 1.82 & -2.61 & 4.67 \\
\hline Text Score & $\begin{array}{l}\text { Unequal } \\
\text { variances }\end{array}$ & & & .56 & 56.78 & .57 & 1.03 & 1.82 & -2.61 & 4.67 \\
\hline
\end{tabular}

According to Table 10 , there was a statistically significant difference in visual learning style scores for males $(M=4.60)$ and females $(M=3.90), t(58)=-2.71, p=.01$ (two-tailed). This is so because the $p$ value is less than the specified level of significance (i.e. .05). Thus, males had significantly better visual scores than did female learners. As for individual learning style, the difference between male $(M=3.86)$ and female $(M=4.56)$ learners was statistically significant. And as for group learning style, the difference between male $(M=4.60)$ and female $(M=3.56)$ learners was statistically significant.

However, for auditory, kinesthetic, and tactile learning styles, the differences between males and females were not found to be statistically significant. With regard to auditory learning style, the difference between males $(M=3.66)$ and females $(M=3.93)$ did not reach statistical significance $(p=.43>.05)$; as for the kinesthetic learning style, male learners $(M=4.16)$ were slightly better than their female counterparts $(M=3.86), p=.32$; however, the difference was not statistically significant. The same result was obtained for tactile learning style, i.e. male learners $(M=3.23)$ performed slightly better than female learners $(M=2.80), p=$ .01; however, the difference was not statistically significant.

Finally, the differences between the learning styles of male and female learners failed to bring about a significant difference in their journalistic reading scores since the obtained $p$ value for comparing males $(M=20.80)$ and females $(M=21.83)$ was greater than the significance level $(.57>.05)$. Accordingly, the differences between the learning styles of male and female EFL learners could not cause significant differences in their journalistic reading scores.

\section{Discussion and Conclusion}

The current study assumed that there is no difference between female and male EFL learners' learning styles and learning styles do not affect EFL learners' performance on reading journalistic text. The results of the present study, however, showed that males and females were significantly different in their visual, group, individual learning styles, but not in their auditory, kinesthetic, tactile learning styles by $t$ test analyses. Moreover, the differences between the learning styles of male and female EFL learners could not bring about significant changes in their reading of journalistic text. The variation of learning style, as observed in the current study has been confirmed in previous studies. Reid (1987), for example, found that the participants in her study strongly performed kinesthetic and tactile learning styles. She found that most groups of students showed a negative preference for group learning. The results obtained showed that auditory and kinesthetic styles were major learning style preferences by humanities while individual.

The results of this study support the previous research findings (Salehi, Lari, \& Rezanejad, 2014; Keshavarz \& Ashtarian, 2008), suggesting that the interaction of gender and genre or text type did not have any significant effect on comprehending texts. Teachers are advised to integrate different kinds of genres in reading courses. They should focus more on genres that students are less exposed to (Salehi, Lari, \& Rezanejad, 2014). Learning was a minor style and the students were the least oriented toward visual and group learning. Every major has its own demand, courses, materials, tasks, and activities. When the students are studying a specific major, their mental state would be affected by the demands of their major, i.e. their learning styles would be changed and modified and as a result, they will choose reading genres which match their styles. At the end of this study, the differences between the learning styles of learners could not bring about significant changes in their reading journalistic texts.

\section{Implications}

Research with native speakers of English strongly suggests that the ability of students to employ multiple learning styles results in greater classroom success (Cronbach \& Snow, 1977; Stewart, 1981 as cited in Reid, 1987). Oxford (2003, p.16) believes that one teaching method cannot be used for all students; "instead of choosing a specific instructional methodology, L2 teachers would do better to employ a broad instructional approach, notebly the best version of the communicative approach that contains a combined focus on form and fluency".

Moreover, curriculum designers and material developers should have constant interaction with both teachers and students. Curriculum designers should allocate enough time in the curriculum for teachers to assess learners' styles and their reading comprehension. Material developers should produce what is incongruent with students' learning styles and their level. Curriculum designers and material developers should collect feedback from teachers and students in order to identify the weaknesses and strengths of their products. 
EFL teachers also should have the opportunity to use appropriate materials and activities that match the learners' learning styles; moreover, reading course instructors should help reading instructors check the learning styles and preferences of their students through learning styles inventories before they begin their first reading classes. Then, reading instructors should plan their programs, taking into account the students' reading scores on previous performance tests and also their preferred learning styles. Curriculum designers should also encourage reading instructors to be flexible in the teaching of reading materials and choosing teaching strategies that are appropriate for their students learning styles.

Funding: This research received no external funding.

Conflicts of Interest: The authors declare no conflict of interest.

\section{References}

[1] Abbaszadeh, Z. (2013). Genre-Based Approach and Second Language Syllabus Design. Social and Behavioral Sciences, 84, $1879-1884$.

[2] Alejandro, J. (2010). Journalism of in the Age of Social Media .University of Oxford.

[3] Alharbi, M. A. (2015). Reading Strategies, Learning Styles and Reading Comprehension: A Correlation Study. Journal of Language Teaching \& Research, 6(6).

[4] Bonyadi, A. (2012). Genre Analysis of Media Texts. Social and Behavioral Sciences, 66, 86-96.

[5] Botella, A. Stuart, K., \& Gadea, L. (2015). A Journalistic Corpus: a Methodology for the Analysis of the Financial Crisis in Spain. Social and Behavioral Sciences, 19, 42-51.

[6] Broersma, M. (2007). Form, Style and Journalistic Strategies. European Newspaper and the

[7] Representation of News, 1880-2005.

[8] Barghi, E. \& Zangoei, A. (2014). Learners' Language Style Preferences and Relationship with their Critical Thinking Ability in an Iranian EFL Context. International Journal of Language Learning and Applied Linguistic World, 6(2), 69-280.

[9] Brantmeier, C. (2003). Does Gender Make a Difference ? Passage Content and Comprehension in Second Language Reading. Reading in a Foreign Language, 15(1), 1-23.

[10] Carbo, M. (1994). Reading Style Inventory. Syosset, N.Y.: National Reading Styles Institute.

[11] Carbo, M. (1989). How to Record Books for Maximum Reading Gains. Syosset, N.Y.: National Reading Styles Institute.

[12] Carbo, M. (1996). Selecting the Right Reading Method. Teaching K-8 27, 1(84), 86-87.

[13] Chambers, A. (1995). Böcker omkringoss - läsmiljö. Norstedts.

[14] Cristina-Lemnaru, A. (2012). Communication Distortions and Linguistic Features in the

[15] Journalistic Style. Social and Behaviraol Sciences 70, 963-968.

[16] Davis, A. Catherine, E. (2004). The Handbook of Applied Linguistics. Blackwell Publishing.

[17] Ellis, R. (1994). The Study of Second Language Acquisition. Oxford University Press.

[18] Franzoni, A, L. Assar, S. (2014). Student Learning Styles Adaption Method Based on Teaching Strategies and Electronic Media. Educational Technology and Society, 12(4), 15-29.

[19] Ghezlon, M., Kordi, L., Nasri Nasrabady (2014). Gender Differences in Reading Strategy Use, Reading Self -Efficacy, and Perceptual Learning Styles among EFL Learners. IJLLALW, 5(1) 609-624.

[20] Gavriliu, D. (2012). From the Print Press to Online Press: Constraints and Liberties of the Journalistic Discourse. Social and Behavioral Sciences, 63, 263-270.

[21] Gunes, C. (2004). Learning Style Preferences of Preparatory School Students at Gazi University.

[22] Hassaskhah, J. Barekat,B. Farhan Asa, N. (2014). Reading Performance on Iranian EFL Learners in Paper and Digital Texts. The Journal of Teaching Language Skills, ser.74/4.

[23] Hicks, W. (2008). Writing for Journalists. Second edition. Master -e-book.

[24] Jhaish, M. (2010). The Relationship Among Learning Styles, Language Learning Strategies, and The Academic Achievement Among the English Majors at Al-Aqsa University. British Library Cataloging in Publication Data.

[25] Johnson, P. (1981). Effects on Reading Comprehension of Language Complexity and Cultural Background of a Text. TESOL Quaterly, 15(2), 169-181.

[26] Ghaffar. M., Tahirov, I. (2013). An Analysis of English Newspaper Articles Written by Iranian and Azaribaijani Journalists: Focus on Redundancy. IOSR Journal of Research

[27] and Method in Educations. Volume 2, Issue2,pp25-27.

[28] Kanninen, E. (2010). Learning Styles and E-Learning .Tempere University of Technology.

[29] Kaminska, P. (2014). Learning Styles and Second Language Education. Cambridge Scholars

[30] Publishing.

[31] Keshavarz, M. \& Ashtarian, S. (2008). The Relationship Between Iranian EFL Learn Gender and Reading Comprehension of Three Different Types of Text.IJAL, 11(1),97-113.

[32] Levin, M.G. \& Haus, G. J. (1985). The Effect of Background Knowledge on the Reading Comprehension of Second Language Learners. Foreign Language Annals, 18(5),391-397.

[33] Wong, L.C. \& Nunan, D. (2011). The Learning Styles and Strategies of Effective Language

[34] Learners. Science Direct System 39(2011)144-163.

[35] Molanazar, H. \& Kamyab,S. (2015). Political and Journalistic Translation Courses and the Market Demand in Iran. European Online Journal of Natural and Social Sciences, 4(2). 
[36] Moghadam, S., Razavi, A. \& Jayervand, H. (2013). THE Iranian ESL Learners Preferred Conceptual Learning Style and the Most Used Intelligence. International Journal of Psychology and Behavioral Research. 2(2), 86-90.

[37] Nosrainia, M. Mojri, Z., \& Sarabcian, E. (2014). Exploring the Relationship Between EFL Learners' Language Learning Styles and Strategies. ( IJLLALW) volume 5(2),253-264.

[38] Njeze, M. (2013).Use of Newspaper and Magazines in the Academic Pursuits of University

[39] Students: Case Study of Covenant University. Library Philosophy and Practice (E-

[40] Journal).

[41] Paltridge, B. (2014). Genre and Second Language Academic Writing. Language teaching 47, pp. 303-318.

[42] Paltridge, B. (1996). Genre, Text Type, and the Language Learning Classroom. ELT Journal

[43] Volume 50/3. Oxford University Press 1996.

[44] Pashler, H. Mcdanial, M. Rohrer,D.\& Bjork,R.(2008). Learning Styles: Concepts and Evidence. Psychological Science in the Public Interest. Volume 9.

[45] Patel, A. (2010). The Survival of the Newspaper in the Digital Age of Communication. Newyork University.

[46] Rudin, R. \& Ibbotsont, T. (2002). An Introduction to Journalism Essential Techniques and

[47] Background Knowledge. Focal Press. First Published.

[48] Semir, V. (2000). Scientific Journalism: Problems and Perspectives. Internal, Microbiol

[49] 3:125-128.

[50] Salehi, M. Lari, Z. Rezanejad, A. (2014). The Effects of Gender and Genre on Language Learners' Reading Comprehension Ability. Science Publishing Group. Educational

[51] Journal 3(5);266-271.

[52] Saraiva Schoder,K. Becker,C. Perna,L.(2006). Reading and Processing a Journalistic Text

[53] Through Relevance Theory ; the Larry Rohter case . ISSN.1678-8931.

[54] Sarasin, L. C. (1999). Learning style perspectives: Impact in the classroom. Madison, Wl: Atwood Publishing.

[55] Shuib, M. (2015). Learning Style Preferences Among Male and Female ESL Students in University - Sains Malaysia. The Journal of Educators online-JEO-ISSN 1547-500x vol 13.

[56] Sheikhi, L. (2009). The Relationship between Learning Styles,Language Learning Strategies and Field of Study of Intermediate EFL Students. Najafabad University thesis.

[57] Shahmohammadi, N. (2011). The Effect of Gender Base Materials on Reading Comprehension . International Journal of Human Resource Studies, 1(2).

[58] Wahl-Jorgensen, Hanitzch.(2003). The handbook of journalism studies. Routledge. ISBN 0-203-87768-3 Master e-book.

[59] Wolf, D. F. (1993). A Comparison of Assessment Tasks Used to Measure FL Reading

[60] Comprehension. The Modern Language Journal,77(iv),473-789.

[61] Ytre-Arne,B.(2013). Women's Magazines and Their Readers: The Relationship Between Textual Features and Practice of Reading . Sage Journals. 